\title{
Wybrane aspekty orientacji przestrzennej głowicy roboczej podczas zmechanizowanego i zautomatyzowanego spawania łukowego
}

\author{
Selected aspects of spatial orientation of the working head \\ during mechanized and automated arc welding
}

\section{Streszczenie}

Orientacja przestrzenna głowicy spawalniczej jest jednym z mniej eksponowanych parametrów technologicznych. Podczas spawania ręcznego robotnik sam dostosowuje technikę prowadzenia elektrody do warunków procesu. W systemach zmechanizowanych i zautomatyzowanych konieczne jest szczegółowe ustalenie wszystkich parametrów geometrycznych wzajemnego ustawienia narzędzia i przedmiotu spawanego, a następnie ich ustawienie lub zaprogramowanie w maszynie. W artykule przedstawiono wybrane aspekty orientacji przestrzennej głowicy roboczej podczas zmechanizowanego i zautomatyzowanego spawania łukowego.

Słowa kluczowe: automatyzacja, robotyzacja, spawanie łukowe, orientacja przestrzenna

\section{Abstract}

The spatial orientation of the welding head is one of the less prominent technology parameters. During manual welding the welder adjusts himself the way of electrodes drive to conditions of welding process. The mechanized and automated systems, it is necessary to determine in detail all parameters of geometric alignment of the tool and the workpiece, and then the setting or programming of the machine. The article presents some aspects of the spatial orientation of the working head during mechanized and automated arc welding.

Keywords: automation; robotics; arc welding; spatial orientation

\section{Wstęp}

Orientacja głowicy spawalniczej, np. końcowego odcinka elektrody w procesach MIG/MAG, TIG czy łuku krytym, to jej kątowe ustawienie w przestrzeni, uzupełnione o wysokość i odsunięcie, odniesione do powierzchni ciekłego jeziorka i krawędzi złącza. Uzależniona jest m.in. od pozycji spawania (naboczna, podolna,...), rodzaju spoiny i typu złącza, możliwości swobodnego manewrowania narzędziem w obszarze wykonywanego połączenia, a także właściwości manipulacyjnych maszyny manipulującej głowicą roboczą w procesach zmechanizowanych i zautomatyzowanych.

Podczas spawania ręcznego robotnik najczęściej sam, na podstawie posiadanej wiedzy i doświadczenia, dostosowuje pochylenie i sposób prowadzenia elektrody do warunków procesu. Niekiedy może to wymagać dużej wprawy oraz zdolności manualnych (rys. 1).

Podczas spawania zmechanizowanego i zautomatyzowanego konieczne jest szczegółowe zdefiniowanie podstawowych

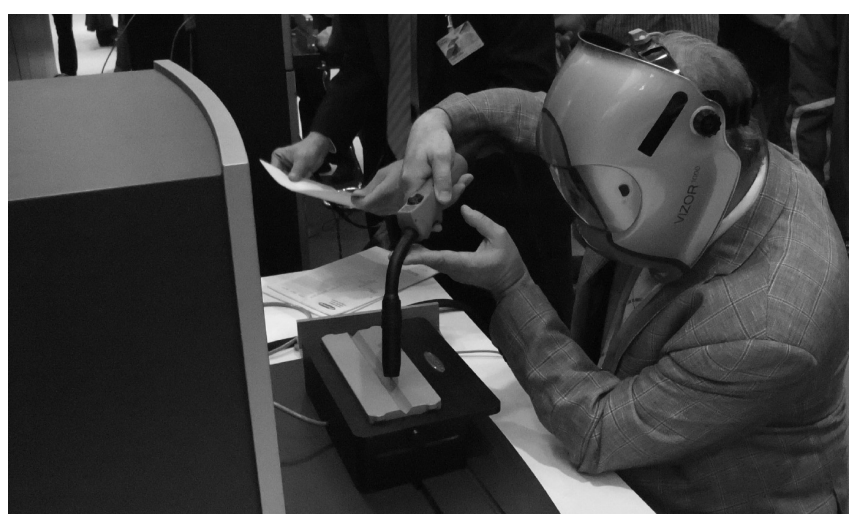

Rys. 1. Prawidłowe manipulowanie ręcznym uchwytem elektrodowym może być doskonalone przy pomocy symulatorów spawalniczych

Fig. 1. Proper handling of manual electrode holder can be improved by means of welding simulators

Dr inż. Paweł Cegielski - Zakład Inżynierii Spajania, Politechnika Warszawska.

Autor korespondencyjny/Corresponding author. pcegiels@wip.pw.edu.pl 
parametrów technologicznych (takich jak prąd spawania, napięcie łuku itp.) w korelacji z parametrami geometrycznymi wzajemnego ustawienia (i ruchu) narzędzia i przedmiotu spawanego. Ich ustalenie stanowi podstawę do zaprogramowania (w systemach zautomatyzowanych) napędów poszczególnych ruchów roboczych. Parametry podstawowe zaprogramowane przed spawaniem często muszą się zmieniać w trakcie procesu, aby uzyskać oczekiwaną jakość i kształt spoiny. Mogą być przy tym dostosowane do geometrii poszczególnych fragmentów złącza, bieżącej pozycji spawania oraz orientacji elektrody omiatającej konstrukcję spawaną.

\section{Parametry orientacji przestrzennej głowicy spawalniczej}

W odniesieniu do orientacji przestrzennej głowicy spawalniczej mogą zostać określone następujące, główne parametry (rys. 2, 3) [2,6,8]:

- Kąt posuwu - zawarty pomiędzy osią narzędzia (np. elektrody) i linią odniesienia, prostopadłą do osi spoiny.

- Kąt pracy (roboczy) - określa przestrzenną orientację osi narzędzia w płaszczyźnie prostopadłej do osi spoiny (kąt zawarty pomiędzy osią narzędzia i normalną do płaszczyzny odniesienia, np. powierzchni materiału rodzimego).

- Wysokość - położenie narzędzia ponad osią spoiny; w przypadku spawania łukowego MIG/MAG oraz łukiem krytym mówimy o tzw. wysunięciu lub wolnym wylocie drutu elektrodowego. Pod tym pojęciem rozumie się odległość pomiędzy końcem elektrody (w miejscu początku łuku spawalniczego) a końcówką (tulejką) prądową (stykową). Dla uproszczenia, zwłaszcza na potrzeby procesów zmechanizowanych i zautomatyzowanych, najczęściej określana jest odległość tulejki prądowej od powierzchni spawanego elementu.

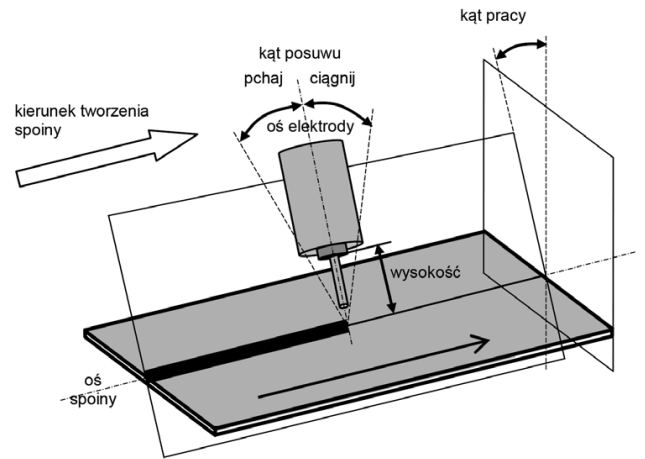

Rys. 2. Podstawowe parametry orientacji przestrzennej głowicy roboczej podczas wykonywania prostoliniowych spoin czołowych [8] Fig. 2. The basic parameters of the spatial orientation of the work head while performing straight butt welds

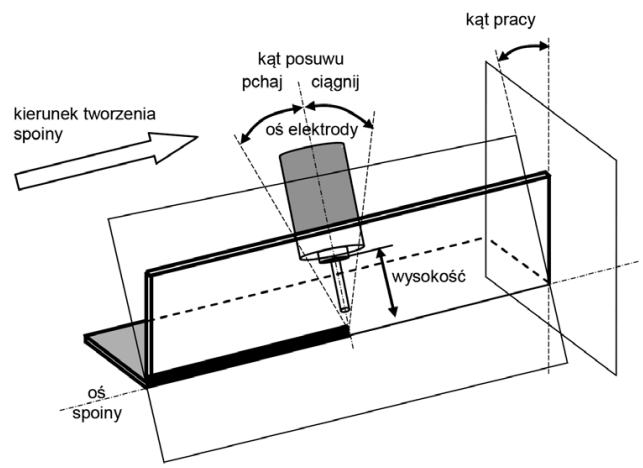

Rys. 3. Podstawowe parametry orientacji przestrzennej głowicy roboczej podczas wykonywania prostoliniowych spoin pachwinowych [8] Fig. 3. The basic parameters of the spatial orientation of the work head while performing straight fillet welds
W przypadku spoin o zarysie krzywoliniowym, np. obwodowych, orientacja przestrzenna głowicy spawalniczej odnoszona jest do powierzchni jeziorka spawalniczego - płaszczyzny stycznej do powierzchni złącza w miejscu chwilowego położenia elektrody (rys. 4). W ten sposób możliwe jest jednoznaczne ustalenie orientacji głowicy spawalniczej dla dowolnie zakrzywionych trajektorii ruchu narzędzia (konturów, po jakich się przemieszczają), typowych dla spawania zrobotyzowanego.

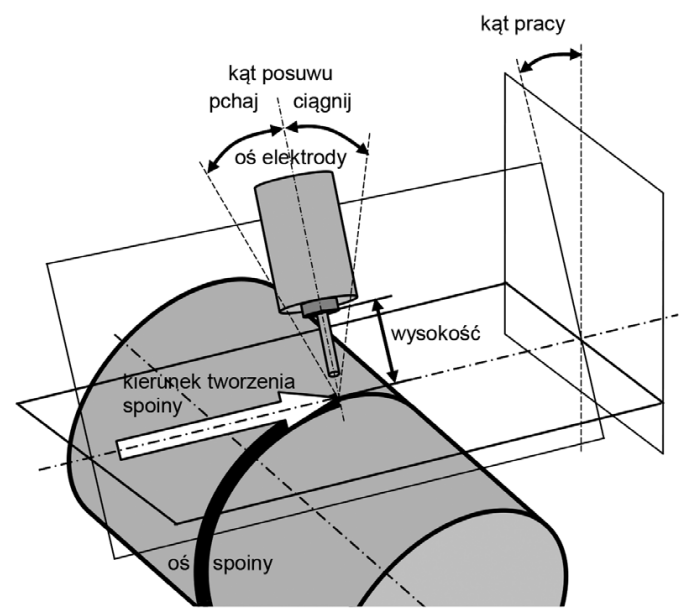

Rys. 4. Podstawowe parametry orientacji przestrzennej głowicy roboczej podczas wykonywania spoin czołowych o zarysie krzywoliniowym Fig. 4. The basic parameters of the spatial orientation of the working head during butt welds processing on outline curvilinear

Na przedstawionych schematach zaznaczono kierunek tworzenia się spoiny. Definiuje on chwilową pozycję narzędzia względem spoiny, nie jest przy tym istotne, czy jest to ruch uchwytu elektrodowego, przedmiotu, czy też równoczesny ruch uchwytu i przedmiotu. Dzięki temu, definiując kąt posuwu można jednocześnie wskazać, przy których wartościach spawanie odbywa się w kierunku „pchaj” lub „ciągnij”. Jak wiadomo, skutkuje to zmianą głębokości wtopienia i geometrii lica spoiny.

Parametrem uzupełniającym, związanym z orientacją przestrzenną głowicy spawalniczej może być odejście, rozumiane jako równoległe odsunięcie osi narzędzia od osi spoiny, obserwowane w płaszczyźnie prostopadłej do osi złącza (rys. 5). Może być konieczne np. przy wykonywaniu metodami MIG/MAG i łukiem krytym spoin pachwinowych w pozycji nabocznej.

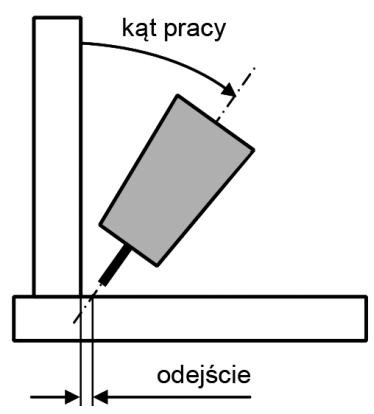

Rys. 5. Zasada oznaczania odejścia

Fig. 5. The way of offset determination

\section{Konsekwencje technologiczne}

Świadome sterowanie orientacją głowicy roboczej może być sposobem na poprawę wtopienia, spawanie bardzo cienkich elementów czy ograniczenie występowania niektórych niezgodności spawalniczych. 
Zmiana kąta posuwu może być sposobem oddziaływania na głębokość wtopienia, a pośrednio, dostosowania do grubości łącznych elementów. Przykładowo, dla metody MIG/ MAG i orientacji neutralnej (kąt posuwu $0^{\circ}$ - oś elektrody ustawiona pionowo względem jeziorka spoiny, rys. 6a), pochylenie w kierunku ciągnij (rys. 6b) spowoduje głębsze wtopienie i mniejszą szerokość lica spoiny, z dobrą ochroną gazową. Pochylenie w kierunku pchającym (rys. 6c) to mniejsze wtopienie i szersze lico spoiny, a ochrona gazowa złącza pogorszy się. Zaznaczony kierunek tworzenia spoiny to, zgodnie z wcześniejszym komentarzem, efekt ruchu narzędzia, przedmiotu lub wynikający z ich połączenia. Ostatni przypadek dotyczy niemal wyłącznie procesów zrobotyzowanych i możliwy jest tylko wtedy, gdy maszyna manipulująca elementami spawanymi (najczęściej pozycjoner) stanowi zewnętrzną oś robota [5] zdolną do wykonywania równoczesnych z nim ruchów roboczych.
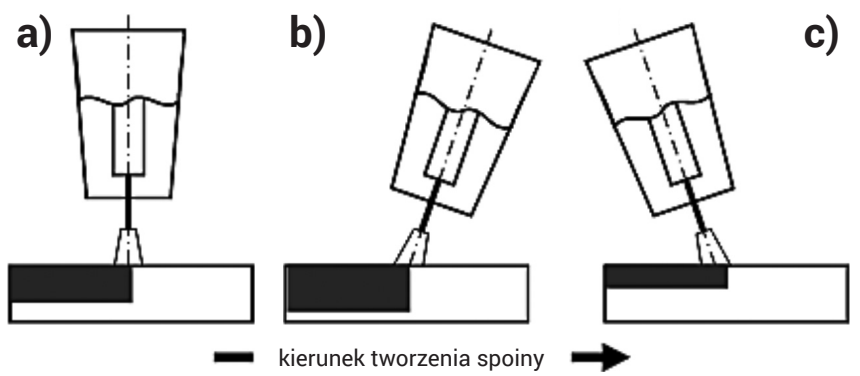

Rys. 6. Idea sterowania kątem posuwu w odniesieniu do kierunku tworzenia spoiny [6]

Fig. 6. The idea of controlling the angle of the feed in relation to the direction of the weld formation

W celu potwierdzenia wpływu kąta posuwu na geometrię złącza przeprowadzono badania podczas napawania zaawansowaną odmianą niskoenergetyczną MAG CMT (ang. Cold Metal Transfer, Fronius). W eksperymencie wykorzystano próbki z blachy DC 04 o wymiarach 60×300x1 mm, o właściwościach oraz składzie chemicznym zestawionych w tablicy I III. Zastosowano drut elektrodowy OK Autrod 12.51 firmy ESAB o średnicy $1 \mathrm{~mm}$ (PN-EN ISO 14341-A-G3Si1). Napawano w osłonie mieszanki $20 \% \mathrm{Ar}+80 \% \mathrm{CO}_{2}$. Parametry napawania ustalono na podstawie nastawnika synergicznego źródła TPS 2700 CMT (Fronius), przyjmując za parametr wiodący grubość próbek: prędkość napawania $20 \mathrm{~mm} / \mathrm{s}$, prąd napawania 83A, napięcie łuku 11,3V [7].

Próby przeprowadzono na stanowisku z robotem IRp-6 (rys. 7), a wpływ zmiany kąta posuwu w zakresie $-300 \div 35^{\circ}$ oceniano $\mathrm{w}$ odniesieniu do próby neutralnej $0^{\circ}$. Kąt pracy dla wszystkich prób wynosił $0^{\circ}$.
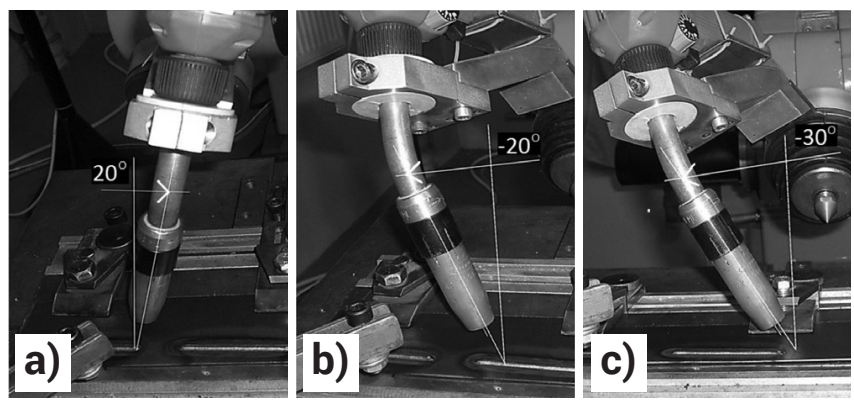

Rys. 7. Zmiana kąta posuwu uzyskana podczas napawania zrobotyzowanego CMT w kierunku: a) ciągnij $20^{\circ}$, b) pchaj $-20^{\circ}$, c) pchaj $-30^{\circ}[7]$ Fig. 7. Changing the angle of the feed achieved in the CMT robot welding, in direction: a) pull of $20^{\circ}$, b) push $-20^{\circ}$, C) push $-30^{\circ}$

W tablicy III przedstawiono wyniki poszczególnych prób. Z uwagi na niewielką grubość próbek (1 mm), zamiast głębokości wtopienia oceniano wysokość napoiny w zestawieniu z obserwacją próbek od strony grani. Przykładowo, przy nastawach kąta posuwu w kierunku pchaj napoiny były szersze i niższe, a jednocześnie od strony grani obserwowano mniejsze wtopienie i węższą strefę wpływu ciepła. Jak widać, pomimo zastosowania znacznie zmodyfikowanej odmiany spawania MAG z pulsacją drutu elektrodowego i dużym, stabilizacyjnym wpływem elektroniki sterującej

Tablica I. Główne właściwości stali DC04 (PN-EN ISO 10152:2009) Table I. Main properties of DC04 steel (PN-EN ISO 10152:2009)

\begin{tabular}{|c|c|c|c|}
\hline Oznaczenie & $\begin{array}{c}\text { Definicja i klasyfikacja } \\
\text { wg EN 10020 }\end{array}$ & Sposób odtleniania & $\begin{array}{c}\text { Granica plastyczności } \\
\text { Re [MPa] }\end{array}$ \\
\hline DC04 & $\begin{array}{c}\text { Stal niestopowa } \\
\text { jakościowa }\end{array}$ & całkowicie uspokojona & 140 do 220 \\
\hline
\end{tabular}

Tablica II. Skład chemiczny stali DC04 (PN-EN ISO 10152:2009)

Table II. Chemical composition of DC04 steel (PN-EN ISO 10152:2009)

\begin{tabular}{|c|c|c|c|c|}
\hline Pierwiastek & C & $P$ & $S$ \\
\hline Zawartość [\%] & 0,08 & 0,03 & 0,03 & 0,4 \\
\hline
\end{tabular}

Tablica III. Uśrednione pomiary napoin: b - szerokość, h - wysokość [7]

Table III. Average results of measurements of padding welds: $b$ - width, $h$ - height [7]

\begin{tabular}{|c|c|c|c|c|}
\hline \multirow{2}{*}{ Numer próby } & \multirow{2}{*}{$\begin{array}{c}\text { Kąt posuwu } \\
{\left[{ }^{\circ}\right]}\end{array}$} & \multicolumn{2}{|c|}{ Wymiary napoiny [mm] } & \multirow{2}{*}{ Uwagi } \\
\hline & & $b$ & $\mathrm{~h}$ & \\
\hline wzorzec & 0 & 3,56 & 1,05 & neutralny \\
\hline $\mathrm{a}$ & 20 & 3,32 & 1,12 & \multirow{2}{*}{ ciągnij } \\
\hline$b$ & 35 & 3,14 & 1,18 & \\
\hline c & -20 & 3,74 & 0,98 & \multirow{2}{*}{ pchaj } \\
\hline$d$ & -30 & 3,78 & 1,06 & \\
\hline
\end{tabular}


na przebieg procesu, w pełni potwierdzono znaną zależność geometrii spoiny od kąta posuwu.

W przypadku wykonywania spoin czołowych zaleca się zwykle pionowe ustawienie osi elektrody (kąt pracy $0^{\circ}$ ). Skutkiem jej nadmiernego pochylenia może być niesymetryczne wtopienie w ścianki złącza czy nieciągłości wtopienia w przypadku spoin dwustronnych (rys. 8).

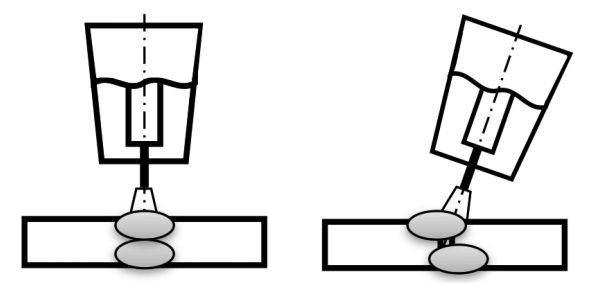

Rys. 8. Prawidłowa orientacja elektrody (kąt pracy $0^{\circ}$ ) i sutek nadmiernego odchylenia podczas wykonywania spoin czołowych [9]

Fig. 8. Proper orientation of the electrodes (angle $-0^{\circ}$ ) and effect of excessive deviation during butt welds performing

W przypadku spoin pachwinowych, kąt pracy ma wpływ na jakość połączeń, w tym powstawanie przyklejeń. Podczas spawania metodami MIG/MAG oraz łukiem krytym w pozycji nabocznej może być dodatkowo wprowadzone odejście - odsunięcie osi elektrody od krawędzi złącza (rys. 9, 10). Podczas spawania łukiem krytym, z uwagi na zwykle znacznie większe średnice elektrod, wydajności stapiania i przekroje jednorazowo uzyskiwanych spoin, w niektórych przypadkach nieco inaczej wygląda zalecana orientacja głowicy roboczej (rys. 10).
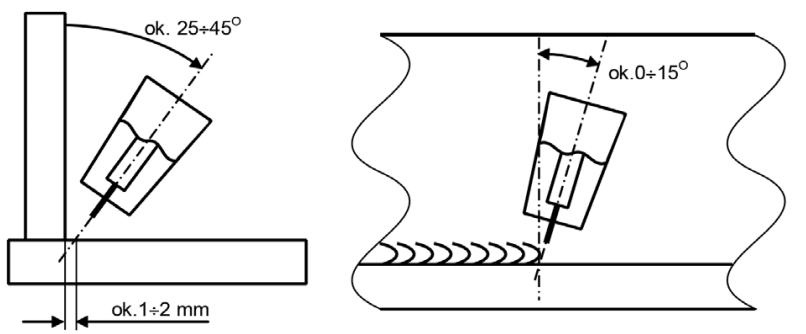

Rys. 9. Zalecana orientacja elektrody podczas wykonywania spoin pachwinowych w pozycji nabocznej MIG/MAG, z zaznaczeniem odejścia osi elektrody od osi spoiny $[6,9]$

Fig. 9. Recommended orientation of the electrodes for fillet welds performing with MIG/MAG in PB, indicating the offset of the electrode axis from the axis of the weld $[6,9]$

Kolejnym, istotnym parametrem orientacji głowicy spawalniczej jest wysokość ponad osią spoiny - wolny wylot drutu elektrodowego $\left(I_{w}\right)$ dla metod MIG/MAG i łuku krytego (rys. 11). Wysunięcie końca drutu z końcówki prądowej uchwytu elektrodowego wpływa na stopień jego podgrzania - im jest większe przy tym samym prądzie spawania, tym większa staje się wydajność jego stapiania (wskutek nagrzewania oporowego). Przy niezmienionych parametrach, ze wzrostem wysunięcia drutu zmniejsza się wartość prądu spawania (wskutek dodatkowej oporności wysuniętego odcinka drutu), aż do zaburzeń stabilności jarzenia się łuku. Przy za krótkim wolnym wylocie łuk będzie się jarzył zbyt blisko końcówki prądowej, powodując jej nadmierne zużycie, a w chwili zakończenia spawania może nastąpić przyklejenie gorącego końca elektrody do końcówki. Długość wolnego wylotu jest uzależniona m.in. od rodzaju i średnicy drutu elektrodowego, natężenia prądu spawania czy napięcia łuku, a także sposobu przechodzenia kropli ciekłego metalu do jeziorka spawalniczego. Podczas spawania metodą MAG łukiem zwarciowym, optymalna długość zawiera się $\mathrm{w}$ przedziale $6 \div 15 \mathrm{~mm}$, a przy natryskowym pomiędzy 18 i $25 \mathrm{~mm}$. [2,6].
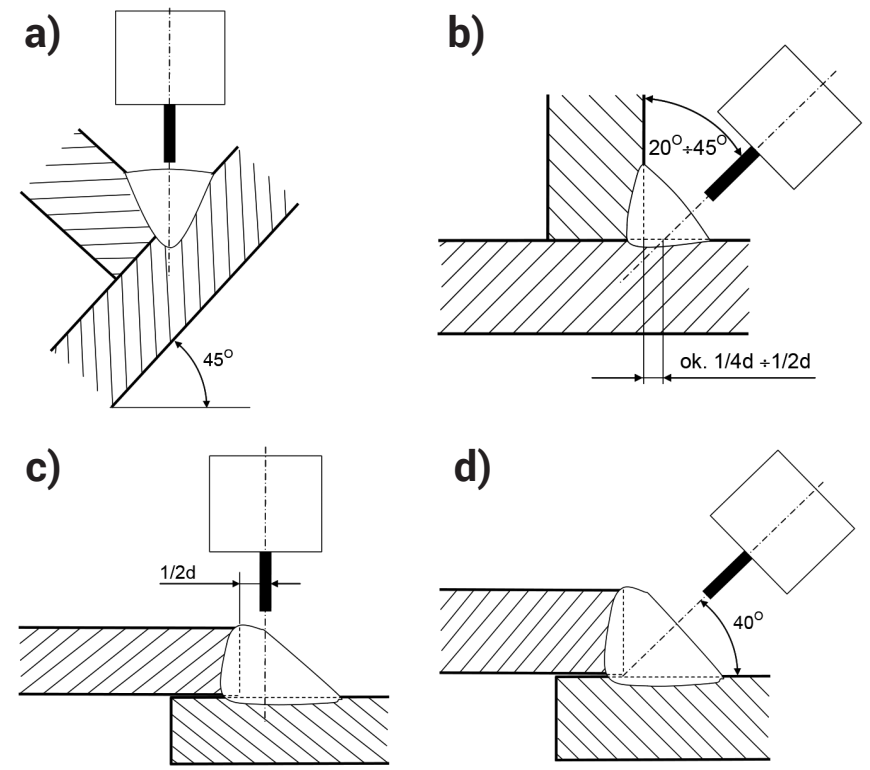

Rys. 10. Zalecane orientacje głowicy roboczej dla spoin pachwinowych wykonywanych łukiem krytym: a) w pozycji podolnej, b) w pozycji nabocznej, c) w złączu nakładkowym dla grubości blach do ok. $5,0 \mathrm{~mm}$, d) w złączu nakładkowym dla grubości blach powyżej 5,0 $\mathrm{mm} ; \mathrm{d}$ - średnica drutu elektrodowego [6]

Fig. 10. Recommended orientation of the working head for fillet weIds during submerged arc welding: a) PA position, b) PB position, c) in the overlap joints for sheet thicknesses up to approx. $5.0 \mathrm{~mm}$ d) in the overlap joints for sheet thicknesses above $5,0 \mathrm{~mm}$; ( $d$ - the diameter of the wire electrode) [6]

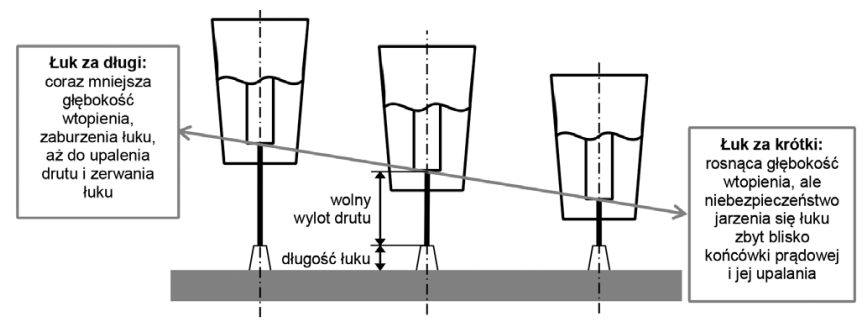

Rys. 11. Geometryczne przedstawienie długości wolnego wylotu drutu elektrodowego podczas spawania MIG/MAG [2,6]

Fig. 11. The geometric presentation the length of the free section of wire electrode during MIG/MAG

W celu zbadania wpływu $I_{w}$ na warunki i efekty spawania, wykonano eksperyment w oparciu o stanowisko i warunki technologiczne jak dla wcześniej opisanej weryfikacji kąta posuwu (tabl. I i II, rys. 7). Wykonano szereg napoin metodą MAG CMT przy różnych nastawach odległości końcówki prądowej do powierzchni próbki. W pierwszej kolejności robot wykonał serię napoin stopniowo odsuwając głowicę (próby a-d), a następnie ją zbliżając (próby e-g) do powierzchni blachy [7].

Zwiększanie długości wolnego wylotu powodowało zwiększanie objętości napoiny. W przypadku procesu CMT i źródła spawalniczego sterowanego synergicznie, następowała automatyczna korekta i dla zwiększającego się wysunięcia drutu nieznacznie wzrastało natężenie prądu spawania i napięcie łuku, powodując zwiększoną wydajność stapiania. Odwrotny skutek przynosiło skracanie $I_{w}$. Najlepszy efekt wizualny osiągnięto przy skróceniu wolnego wylotu do $12 \mathrm{~mm}$, a więc poziomu zalecanego przy zwarciowym przenoszenia ciekłego metalu, występującego także w odmianie CMT. Dalsze wydłużanie $\mathrm{I}_{\mathrm{w}} \geq 23 \mathrm{~mm}$ powodowało znaczne pogorszenie jakości napoiny. Dodatkowo, w przypadku spawania zrobotyzowanego MIG/MAG, zbyt duże wysunięcie końca elektrody może przyczynić się do pogorszenia jakości spoin poprzez zakłócenie chwilowego położenia łuku spawalniczego względem wcześniej zdefiniowanego punktu roboczego narzędzia TCP (ang. Tool Centre Point) [1]. 
Tablica IV. Uśrednione pomiary napoin: b - szerokość, h - wysokość [7]

Table IV. Average results of measurements of padding welds: $b$ - width, $\mathrm{h}$ - height [7]

\begin{tabular}{|c|c|c|c|c|}
\hline \multirow{2}{*}{ Numer próby } & \multirow{2}{*}{$\mathrm{I}_{\mathrm{w}}[\mathrm{mm}]$} & \multicolumn{2}{|c|}{ Wymiary napoiny $[\mathrm{mm}]$} & \multirow{2}{*}{ Uwagi } \\
\cline { 3 - 4 } & & $\mathrm{b}$ & $\mathrm{h}$ & \multirow{2}{*}{ wartość bazowa } \\
\hline $\mathrm{y}$ & 14 & 3,52 & 1,14 & \multirow{2}{*}{ kierunek rosnący } \\
\hline b & 17 & 3,72 & 1,26 & \multirow{2}{*}{ wartość bazowa } \\
\hline c & 20 & 3,94 & 1,44 & \multirow{2}{*}{ kierunek malejący } \\
\hline d & 23 & 4.08 & 1,52 & 1,02 \\
\hline
\end{tabular}

\section{Zapewnienie założonej orientacji}

Wzajemne ustawienie złącza (pozycji spawania) i orientacji głowicy spawalniczej, np. uchwytu elektrodowego MIG/MAG, zawsze będzie kompromisem pomiędzy wieloma czynnikami: - technologicznymi, związanymi m.in. z wyborem najdogodniejszej pozycji spawania i orientacji narzędzia dla określonego typu złącza i rodzaju spoiny,

- manipulacyjnymi, które w procesach zmechanizowanych i zautomatyzowanych są wypadkową złożoności geometrycznej spawanej konstrukcji, dostępu do miejsca spawania, zastosowanego oprzyrządowania montażowego oraz możliwości użytych urządzeń manipulujących przedmiotem spawanym i/lub narzędziem,

- techniczno - ekonomicznymi, uwzględniającymi występowanie w ofercie producentów odpowiednich urządzeń manipulacyjnych oraz ich akceptowalnej ceny.

Zapewnienie założonej orientacji głowicy roboczej, zwłaszcza w przypadku złożonych zarysów spoin, ograniczonego dostępu do miejsca spawania czy potrzeby wykonania w jednej operacji szeregu różnie rozmieszczonych połączeń wieloelementowej konstrukcji, może wymagać zastosowania robota wraz z dodatkowymi maszynami manipulacyjnymi, tzw. zewnętrznymi osiami robota, a przede wszystkim wieloosiowymi pozycjonerami [5]. Najlepiej, jeśli pozycjoner zdolny jest do wykonywania ruchów roboczych równocześnie z ruchami robota. Wysoka cena tego typu urządzeń stanowić będzie jednak istotne ograniczenie ekonomiczne.

W pewnych warunkach pomocne w uzyskaniu poprawnej spoiny może być skorygowanie podstawowych parametrów spawania. Przykładowo, w procesach MIG/MAG stosując łuk ze zwarciowym przenoszeniem kropli ciekłego metalu do jeziorka (tzw. łuk krótki, ang. short arc) można dopuścić większą tolerancję ustawienia elektrody, natomiast przy łuku natryskowym niewłaściwe ustawienie uniemożliwia kontrolę nad dużym jeziorkiem, powodując przepalenie lub wyciekanie metalu.

W przypadku spawania zmechanizowanego, a zwłaszcza zautomatyzowanego i zrobotyzowanego, istotnym problemem może być powtarzalne usytuowanie węzłów spawanych względem głowicy spawalniczej (ustalonej mechanicznie lub poruszającej się po zaprogramowanej trajektorii). Przyczyną takiego stanu może być m.in. niedokładność wykonania spawanych elementów, błędy ich złożenia w oprzyrządowaniu montażowym, deformacje pod wpływem procesu spawalniczego itp., a także błędy zamocowania i/lub ruchu samego narzędzia. W konsekwencji, zmianie ulegną założone parametry orientacji głowicy spawalniczej, przede wszystkim jej wysokość i odejście (rys. 12,13). a)
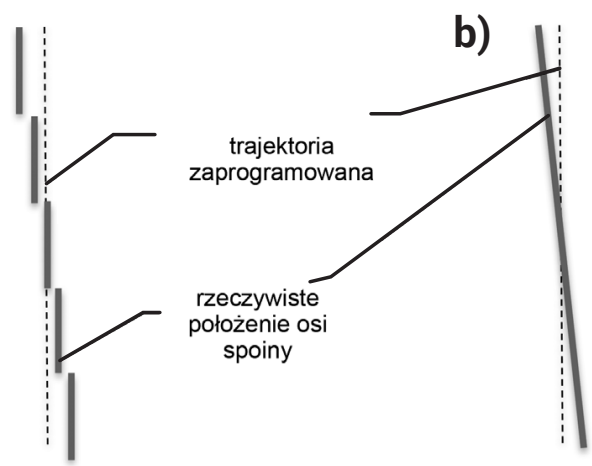

Rys. 12. Schematyczne przedstawienie błędów odejścia końca elektrody od osi spoiny wskutek: a) równoległego przesunięcia, b) obrotu faktycznej osi wykonywanego złącza w stosunku do pierwotnie zaprogramowanej

Fig. 12. Schematic representation of offset errors as a effect of: a) a parallel shift, b) the actual rotation axis of the joint in relation to the originally programmed

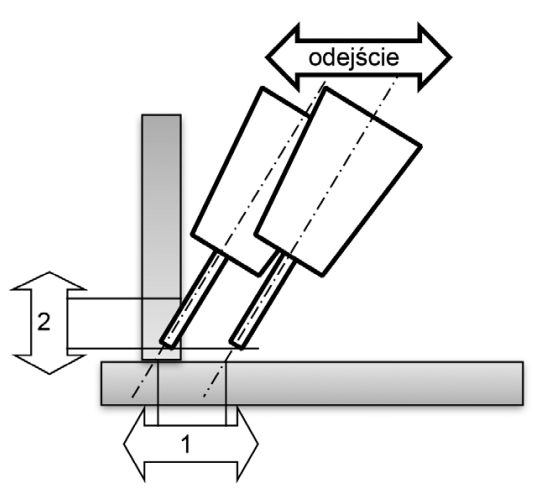

Rys. 13. Błędy odejścia końca elektrody od osi spoiny mogą skutkować: 1) przesunięciem poziomym, 2) zmianą wysokości aktywnego końca elektrody

Fig. 13. Offset errors of the electrode from the center of the weld may result in: 1) the horizontal displacement, 2) a change in the amount of active end of the electrode

W celu wykazania wpływu błędów odejścia końca elektrody na poprawność wykonania złącza, wykonano testowe spoiny czołowe w pozycji podolnej oraz pachwinowe w pozycji nabocznej metodą MAGPuls (sterowanie synergiczne). W eksperymencie wykorzystano metaliczne czyste próbki z powszechnie stosowanej stali konstrukcyjnej St3S (S235) o wymiarach $50 \times 100 \times 3 \mathrm{~mm}$. Jak poprzednio, zastosowano drut elektrodowy OK Autrod 12.51 firmy ESAB o średnicy $1 \mathrm{~mm}$ (PN-EN ISO 14341-A-G3Si1). Spawano w osłonie mieszanki $20 \% \mathrm{Ar}+80 \% \mathrm{CO}_{2}$. Parametry napawania ustalono 
na podstawie nastawnika synergicznego źródła TPS 2700 CMT (Fronius), przyjmując za parametr wiodący grubość próbek: prędkość napawania $13 \div 16 \mathrm{~mm} / \mathrm{s}$, prąd napawania $125 \mathrm{~A}$, napięcie łuku $21,8 \mathrm{~V}$. Dla prób ze spoinami pachwinowymi ustalono kąt pracy $45^{\circ}$, kąt posuwu $0^{\circ}$. Dla spoin czołowych kąty pracy i posuwu wynosiły $0^{\circ}$.

$\mathrm{Na}$ stanowisku zrobotyzowanym zaprogramowano ruch elektrody skośnie do rzeczywistego położenia osi złącza, symulując w ten sposób obrót trajektorii w płaszczyźnie poziomej $X-Y$. Uzyskano odchyłkę końca elektrody w stosunku do rzeczywistego położenia osi spoiny w zakresie ok. +/- $4 \mathrm{~mm}$ (rys. 14):

- średnia odchyłka A dla spoiny pachwinowej: 3,60 mm,

- średnia odchyłka B dla spoiny pachwinowej: 3,78 mm,

- średnia odchyłka A dla spoiny czołowej: $3,77 \mathrm{~mm}$,

- średnia odchyłka B dla spoiny czołowej: 3,26 mm,

Możliwość tak dokładnych odczytów zapewniał układ sterowania robota. Na rysunku 15 przedstawiono wybrane efekty przeprowadzonych prób. Zaznaczono rzeczywisty przebieg rowka, zaprogramowaną trajektorię robota oraz odcinki spoin o akceptowalnej geometrii (orientacyjnie). Długość spoin wynosiła ok. $70 \mathrm{~mm}$. Strzałki oznaczają kierunek spawania.

Oceny spoin dokonywano m.in. na podstawie oględzin zewnętrznych i pomiarów geometrycznych. Zaobserwowano bardzo niską tolerancję na poziome (w płaszczyźnie X-Y) odchylenia
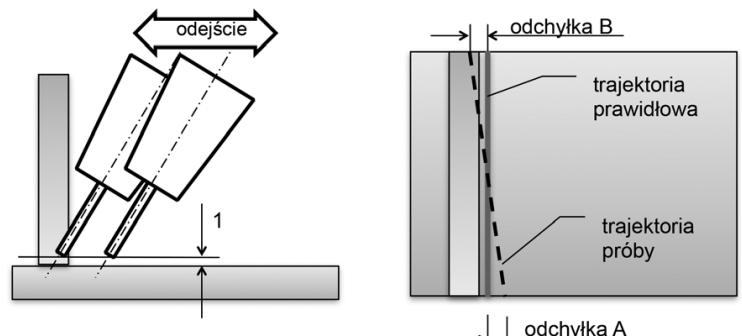

Rys. 14. Schemat próby dla spoiny pachwinowej

Fig. 14. Diagram of trial for a fillet weld a)

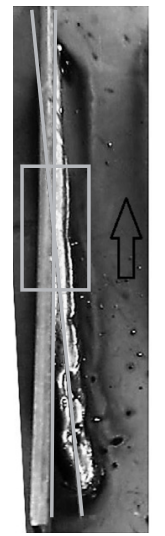

Rys. 15. Widoki spoin uzyskanych podczas prób z trajektorią obróconą w płaszczyźnie poziomej X-Y: a) spoina pachwinowa, b) spoina czołowa Fig. 15. The views of welds obtained during tests with trajectory rotated in a horizontal plane $X-Y$ : a) a fillet weld, b) butt

trajektorii ruchu robota od rzeczywistego położenia rowka spoiny. Dla spoin pachwinowych odchylenie rzędu +/- 0,5 mm praktycznie wyklucza prawidłową spoinę (rys. 15a). Dodatkowo, w początkowej fazie wykonywania spoin pachwinowych obserwowano niestabilne jarzenie się łuku i zniekształcenia lica, wywołane niekorzystną orientacją elektrody (kąt pracy $45^{\circ}$ ) w strefie praktycznie napawania na poziomym elemencie złącza. Podobnie w przypadku spoin czołowych - z punktu widzenia obserwacji lica spoiny, dopuszczalna jest nieco większa odchyłka trajektorii, jednak widok od strony grani jest mniej tolerancyjny (rys. 15b). Ostatecznie, dopuszczalne odchylenie dla spoin czołowych osiąga zbliżony poziom jak dla spoin pachwinowych. Osiągnięte wyniki pokrywają się z podawaną w literaturze dopuszczalną niedokładnością składania części do spawania zautomatyzowanego metodą MIG/MAG na poziomie +/- 0,5 mm. W miarę wzrostu grubości łączonych elementów, a więc i przekroju poprzecznego spoiny, dopuszczalna odchyłka nieznacznie wzrośnie.

\section{Wnioski}

Orientację głowicy spawalniczej należy rozumieć szerzej, jako zespół parametrów geometrycznych opisujących ustawienie kątowe z dodaniem liniowego odejścia i wysokości usytuowania roboczego odcinka elektrody (w procesach łukowych) w stosunku do ciekłego jeziorka i rowka spoiny.

W procesach zmechanizowanego i zautomatyzowanego spawania łukowego prawidłowe ustawienie głowicy roboczej wymaga od operatora lub programisty intuicji i doświadczenia popartego choćby elementarną wiedzą. Orientacja głowicy jest jednym z istotnych warunków uzyskania poprawnego połączenia, a dodatkowo jest skuteczną metodą sterowania geometrą spoiny - głębokością wtopienia, szerokością lica itp.

Nieprawidłowe usytuowanie głowicy roboczej może być spowodowane nie tylko błędami operatora lub programisty, ale także niedokładnością wykonania i złożenia spawanych elementów, ich deformacją pod wpływem realizowanego procesu, a także niedoskonałością pracy użytych maszyn manipulacyjnych. Jak pokazały testy, tolerancja na poziome (w płaszczyźnie X-Y) odchylenie osi elektrody MIG/MAG od osi złącza jest minimalna.

W systemach zrobotyzowanych błędy położenia i orientacji głowicy spawalniczej mogą być korygowane przy pomocy układów sensorycznych, np. detekcji dotykowej, śledzenia łukiem spawalniczym czy z wykorzystaniem czujników laserowych [3,4]. Niestety, takie działanie zawsze pociągnie za sobą dodatkowe koszty, zarówno bezpośrednie (cena zakupu i instalacji) jak i pośrednie, np. wskutek znacznego wydłużenia operacji wymagających skanowania powierzchni złącza przed, a nie w trakcie spawania. Znane są także technologiczne metody zaradcze. Przykładowo, wydłużenie łuku spawalniczego (poprzez podwyższenie albo korektę napięcia w układach synergicznych) powoduje zwiększenie szerokości lica spoiny, a zatem obszaru prawdopodobnego wykonania spoiny. Należy jednak pamiętać o zmniejszonej głębokości wtopienia mogącej spowodować brak pełnego przetopu, a nawet przyklejenia.

\section{Literatura}

[1] Cegielski P. „Analiza uwarunkowań zapewnienia punktu roboczego narzędzia w zrobotyzowanych aplikacjach MIG/MAG" Przegląd Spawalnictwa 8/2014, str. 34-40.

[2] Cegielski P., Kolasa A. „Poradnik spawalniczy. Mechanizacja, automatyzacja, osprzęt" ZASO, Warszawa 2014

[3] Cegielski P., Kolasa A., Golański D., Sarnowski T., Oneksiak A. „Innowacyjne roz wiązania konstrukcyjne w przemysłowych urządzeniach do automatyzacji procesów spawalniczych" Przegląd Spawalnictwa 1/2013, str. 30 - 35.

[4] Cegielski P., Kolasa A., Sarnowski T. „Dostosowanie robotów do spawania elementów o obniżonej dokładności" Przegląd Spawalnictwa 6/2011, str. 25 - 28.
[5] Cegielski P., Kolasa A., Sarnowski T. "Nowe konstrukcje pozycjonerów jako zewnętrznych osi robotów przemysłowych" Przegląd Spawalnictwa 1/2016.

[6] Ferenc K., Cegielski P. i inni (praca zbiorowa) „Technika spawalnicza w praktyce. Poradnik inżyniera konstruktora i technologa". Verlag Dashofer, Warszawa 2015.

[7] Gawroński A. „Niskoenergetyczne odmiany spawania łukowego w osłonach gazowych" Praca dyplomowa inżynierska, kierujący pracą dr inż. Paweł Cegielski, Warszawa 2009.

[8] Malin V. „Designer's guide effective welding automation - part I: analysis of weIding operations as objects for automation" Welding Journal 11/1985.

[9] Pierożek B., Lassociński J. "Spawanie łukowe w osłonach gazowych” WNT, Warszawa 1987. 